\title{
Revision of the Early Jurassic arthropod trackways Camurichnus and Hamipes
}

\author{
Patrick R. Getty
}

Patrick R. Getty

PGonsoulinGetty@collin.edu

Department of Geology, Collin College, 2800 E. Spring Creek Parkway, Plano, Texas 75074, United States of America.

BOL. SOC. GEOL. MEX. 2018

VOL. 70 NO. 2

P. $281-292$

http://dx.doi.org/10.18268/BSGM2018v70n2al

\section{ABSTRACT}

The ichnogenera Camurichnus and Hamipes have been reevaluated based on examination of their type specimens, and their geographic and stratigraphic ranges determined based on a review of the literature. The characteristics used to distinguish Camurichnus (originally erected as Sagittarius) and its included ichnospecies alternans, have been observed in Bifurculapes laqueatus and therefore Camurichnus alternans is considered a junior subjective synonym of $B$. laqueatus herein. Hamipes is a distinct ichnogenus that can be differentiated from similar ichnotaxa by the number, shape, and arrangement of the tracks. Cretaceous trackways from Spain that were attributed to Hamipes belong to Bifurculapes. Additionally, the species $H$. molassicus is moved to the ichnogenus Conopsoides. Since the only other occurrence of Hamipes was the type specimen, the ichnogenus is again known only from the Early Jurassic of Massachusetts, U.S.A. The ichnotaxonomic reassignment, however, extends the geographic and stratigraphic range of Bifurculapes to the Cretaceous of Europe.

Keywords: Deerfield Basin, Newark Supergroup, Ichnology, Ichnotaxonomy, Sagittarius.

\section{RESUMEN}

Los icnogéneros Camurichnus y Hamipes han sido revaluados con base en sus especimenes tipo, y sus rangos geográficos y estratigráficos han sido determinados con base en revisión de literatura. Las características usadas para distinguir Camurichnus (originalmente erigido como Sagittarius) y su icnoespecie incluida alternans, han sido observadas en Bifurculapes laqueatus y por lo tanto, Camurichnus alternans es considerado un sinónimo junior subjetivo de $\underline{B}$. laqueatus. Hamipes es un icnogénero distinto, que puede ser diferenciado de icnotaxa similares por el número, forma y arreglo de las huellas. Huellas del Cretácico que fueron atribuidas a Hamipes, pertenecen a Bifurculapes. Además, la icnoespecie $\underline{H}$. molassicus se traslada al icnogénero Conopsoides. Dado que el único registro alternativo de Hamipes era el ejemplar tipo, el icnogénero de nuevo es conocido sólo por el Jurásico Temprano de Massachusetts, Estados Unidos. Sin embargo, la reasignación icnotaxonómica extiende los rangos geográfico y estratigráfico de Bifurculapes al Cretácico de Europa.

Palabras clave: Cuenca de Deerfield, Supergrupo Nezeark, Icnología, Icnotaxo nomía, Sagittarius. 


\section{Introduction}

Hamipes and Camurichnus (originally erected by Hitchcock [1865] as Sagittarius) are among the 31 invertebrate ichnogenera that Edward Hitchcock erected during the nineteenth century based on specimens from the Mesozoic rift basins of southern New England (Rainforth, 2005). The large number of invertebrate ichnotaxa that Hitchcock established resulted, in large part, from a lack of standard criteria for establishing ichnotaxa, guidelines for which have recently been established (e.g, Demathieu and Demathieu, 2003; Bertling et al., 2006; Minter et al., 2007). Lacking such standardized guidelines, Hitchcock sometimes muddled the distinction between his ichnotaxa by establishing new ones for specimens with seemingly minor morphological differences, while simultaneously placing specimens with very different morphologies into the same ichnotaxon (Minter and Braddy, 2009). Various authors (e.g., Keighley and Pickerill, 1998; Rainforth, 2005; Minter and Braddy, 2009) have argued that the number of ichnotaxa Hitchcock established is excessive, and that subjective synonymies likely exist. Identifying subjective synonyms, however, is hampered by the fact that many of Hitchcock's ichnogenera were poorly illustrated and described. In fact, Hitchcock (1858) occasionally acknowledged that his illustrations left much to be desired, as he did for Halysichnus laqueatus. Indeed, Goldstein et al. (2017) recently reevaluated Halysichnus and showed that it is a subjective senior synonym for the well-known burrow Treptichnus. Häntzschel (1975) included nine of Hitchcock's ichnogenera in a list of unrecognizable taxa because of the poor quality of the original descriptions and illustrations.

The present study, which constitutes a revision of Camurichnus and Hamipes, is part of an ongoing effort to redescribe, refigure, and reevaluate Hitchcock's invertebrate ichnogenera. A main focus of this study is to determine whether Camurichnus and Hamipes are distinguishable from other ichnogenera that Hitchcock described. Evidence is presented herein that supports the synonymization of Camurichnus with Bifurculapes, whereas Hamipes is considered a distinct taxon. The ichnogeneric diagnoses for Bifurculapes and Hamipes are revised, and a brief discussion of the stratigraphic and geographic distributions of the ichnogenera is presented.

\section{Geological Context}

The lectotype of Hamipes didactylus was found on a farm at Turners Falls, and the two specimens Hitchcock attributed to Camurichnus alternans were found at a site known as the Lily Pond (Hitchcock, 1858, 1865). Geographically, both of these sites are in the town of Gill, Massachusetts (Figure 1a, b). Geologically, they are part of the Deerfield Basin and their rocks are derived from the Turners Falls Formation, which is two km thick and consists of playa/playa lake redbeds and gray to black lacustrine strata, along with minor fluvial strata (Olsen et al., 1992; Hubert and Dutcher, 2005; Figure 1c, d). The fossils appear to have been produced in a permanent lake due to the gray color of the slabs on which they are preserved.

The Deerfield Basin is part of the Newark Supergroup, which formed in eastern North America in the Late Triassic to Early Jurassic as Pangea fragmented and the early Atlantic Ocean formed (Olsen, 1978; Olsen et al., 1992). Basin sedimentation began with the accumulation of coarse fluvial sediment of the Sugarloaf Formation in the Late Triassic. In the Early Jurassic, however, crustal extension rates increased and an asymmetrical, east-dipping half graben formed as border faults on the eastern margin of the basin coalesced (Schlische and Olsen, 1990). As the basin deepened, lacustrine sedimentation began, forming the Fall River Beds and Turners Falls Formation. These lacustrine strata are separated by volcanic rocks of the Deerfield Basalt, which formed during a period of widespread volcanism throughout Pangea (Olsen et al., 1996). The lake deposits exhibit cyclically alternating layers of red, mud-cracked mudstone and sandstone formed in 


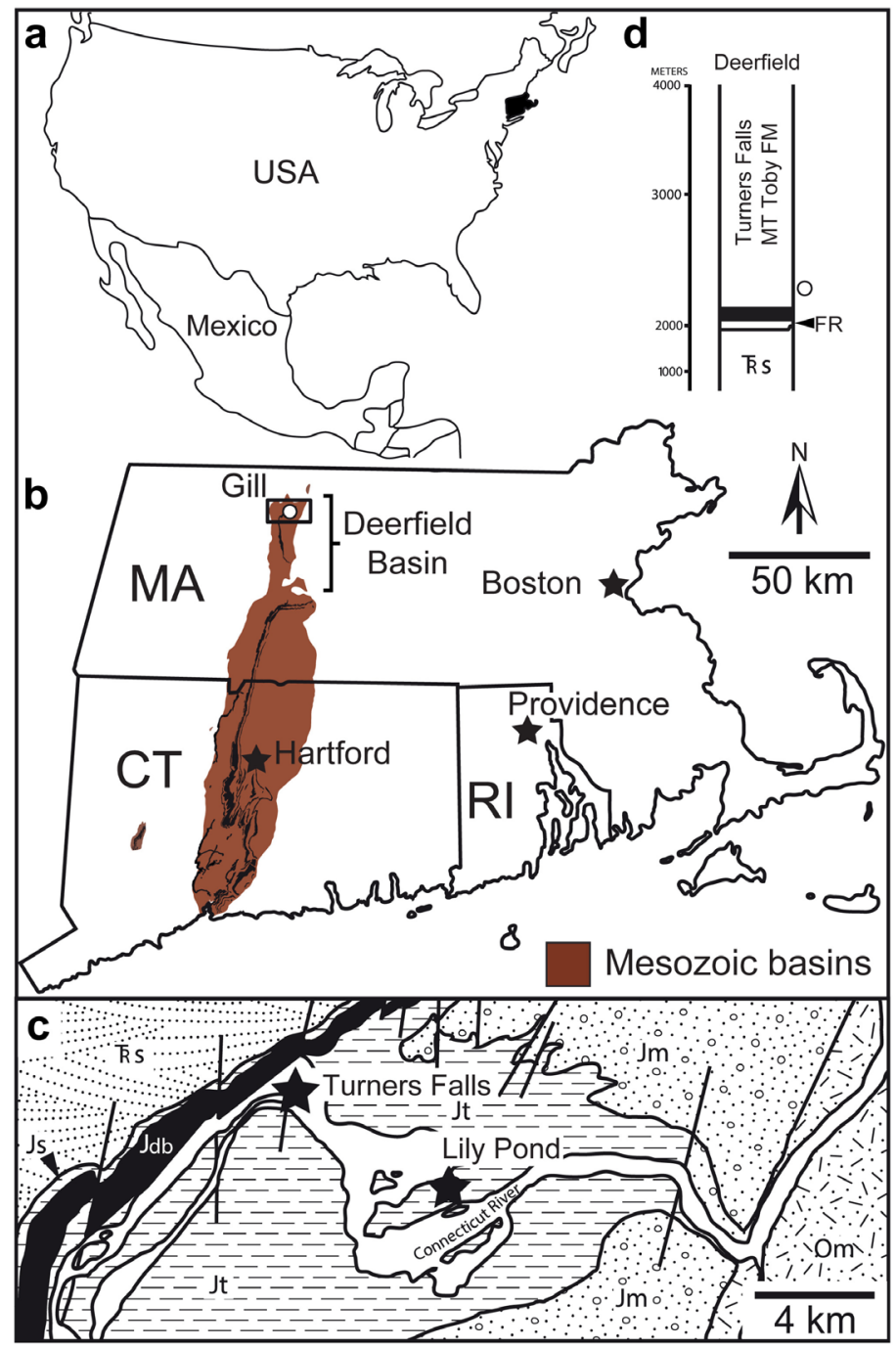

Figure 1 Geographical and geological context of Hamipes and Camurichnus. a) Sketch map of North America with southern New England shaded black. b) Map of southern New England, including Connecticut (CT), Massachusetts (MA), and Rhode Island (RI), showing the extent of the early Mesozoic basins and the location of the town of Gill, in which the specimens were found. Sedimentary rocks are brown; igneous rocks are black. Starred cities are state capitals. c) Close-up of the boxed region in b) showing the bedrock geology of the region in which the fossils were collected. Map modified from Zen et al. (1983). d) Simplified stratigraphic column of the Deerfield Basin showing the approximate position from which the fossil trackways were collected. Abbreviations are as follows: Jdb, Jurassic Deerfield Basalt; Jm, Jurassic Mount Toby Formation; Js, Jurassic Sugarloaf Formation; Jt, Jurassic Turners Falls Formation; Om, Ordovician Moretown Formation; Trs, Triassic Sugarloaf Formation.

playas along with gray to black shale formed in deep, permanent bodies of water. Olsen (1986) ascribed these cycles to Milankovitch cycle-influenced climate changes. Models indicate that the paleoclimate of the Deerfield basin was monsoonal (Parrish, 1993), and sedimentological evidence indicates that there was a long dry season (Hubert, 1978). Sedimentation in the basin is thought to have ceased by the Middle Jurassic (Olsen et al., 1992).

\section{Methodology}

The specimens examined for this study are housed at the Beneski Museum of Natural History at 


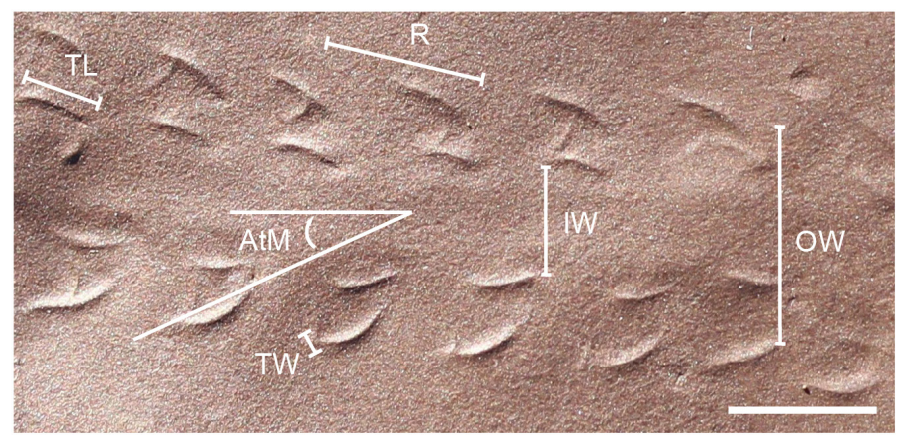

Figure 2 Measurements recorded from trackways. Abbreviations are as follows: angle to midline for the track (AtM), inner trackway width (IW), outer trackway width (OW), repeat distance between tracks (R), track length (TL), and track width (TW). Specimen is ACM ICH 300, a Bifurculapes laqueatus from the early Jurassic East Berlin Formation of the Hartford Basin in Holyoke, Massachusetts. Scale bar equals $5 \mathrm{~mm}$.

Amherst College, the Museum of Comparative Zoology at Harvard University, and the Peabody Museum of Natural History at Yale University. The abbreviation for the Beneski Museum of Natural History is ACM. The acronym ICH, following ACM, denotes that the specimens are part of the ichnology collection. Each specimen was examined and photographed under low-angle light. To ensure that all trackway features were observed, the specimens were sequentially examined with light coming from different directions. Measurements were taken from the photographs using the public-domain image-processing and analysis program ImageJ (Rasband, 1997-2015). The measurements included track length, track width, angle to midline for the track, repeat distance between tracks, inner trackway width, and outer trackway width (Figure 2). Simple morphometric analyses were conducted from the measurements to quantify differences between the ichnotaxa.

Bertling et al. (2006) and Minter et al. (2007) have proposed a series of principles for dealing with the taxonomy of arthropod trackways that I follow in preparing the systematic ichnology section below. For example, I follow Bertling et al. (2006) in considering undertracks and other poorly defined traces as being unsuitable to serve as type specimens and consider them to be nomina dubia. Additionally, following Minter et al. (2007), I consider ichnogeneric synonymization justified when specimens exhibit intergradation resulting from minor behavioral changes within ethological categories (e.g, changes of gate during walking), but not when the change in morphology results from behavioral differences that would be considered discrete ethological categories (e.g., changing from crawling to digging).

\section{Systematic Ichnology}

Ichnogenus Bifurculapes Hitchcock, 1858

non 1769 Sagittarius; Vosmaer.

non 1783 Sagittarius; Hermann.

1858 Bifurculapes; E. Hitchcock, p. 152.

1865 Sagittarius; Hitchcock, p. 16, plate 6 figure 3,

plate 18 figure 5 .

1889 Sagittarius; Hitchcock, p. 119.

1915 Sagittarius; Lull, p. 61.

1953 Sagittarius; Lull, p. 46.

1975 Sagittarius; Häntzschel, p. W191.

2000 Hamipes; de Gibert et al., p. 93, figure 3A, B.

2005 Camurichnus; Rainforth, p. 836.

Type species. Bifurculapes laqueatus Hitchcock, 1858, designated by Lull (1953, p. 42).

Other species. Bifurculapes scolopendroideus Hitchcock, 1858.

Occurrence. Early Jurassic (Hettangian), Turners Falls Formation of the Deerfield Basin, East Berlin Formation of the Hartford Basin, and Moenave 
Formation of the Zuni sag within the U.S.A., as well as the Early Cretaceous (BerriasianValanginian) La Sierra del Montsec thrust sheet of northern Spain.

Emended Diagnosis. A trackway consisting of two rows of elongate, straight or crescentic imprints arranged in staggered to alternating series of one to three tracks. Tracks are of different lengths, with the two larger tracks in each series oriented posterolaterally and their anterior tips forming a line nearly perpendicular to the trackway midline. The smallest track is oriented oblique or perpendicular to the trackway axis. The longest track is almost always on the outside of the trackway, with the middle length track on the inside and the smallest track between the other two.

Remarks. Häntzschel (1975) noted that Hitchcock's (1865) usage of the name Sagittarius created a junior homonym, and Rainforth (2005) later provided the replacement name Camurichnus. Considering that the purported diagnostic characters of Camurichnus are seen in some Bifurculapes specimens, the former is considered a junior synonym of the latter. Getty (2016) provided a revised ichnogeneric diagnosis for Bifurculapes, and that diagnosis is further revised here in order to accommodate the Camurichnus morphology. Getty (2016) also proposed a synonymy in which he recognized only two ichnospecies within Bifurculapes, B. scolependroideus and B. laqueatus, because some trackways exhibited morphologies that intergraded between B. curvatus, B. elachistotatus, and B. laqueatus. Lull (1953) designated Bifurculapes laqueatus the type species so it was retained as the senior synonym.

Bifurculapes laqueatus Hitchcock, 1858

$$
\text { (figures 3, 4) }
$$

1858 Bifurculapes laqueatus; Hitchcock, p. 153. 1865 Sagittarius alternans; Hitchcock, p. 16, plate 6

figure 3, plate 18 figure 5 .

1889 Sagittarius alternans; Hitchcock, p. 119.

1915 Sagittarius alternans; Lull, p. 61.

1953 Sagittarius alternans; Lull, p. 46.

1975 Sagittarius alternans; Häntzschel, p. W191.

2005 Camurichnus alternans; Rainforth, p. 836.

Emended Diagnosis. Bifurculapes with one to three tracks per series and a regularly repeating, alternate trackway pattern.
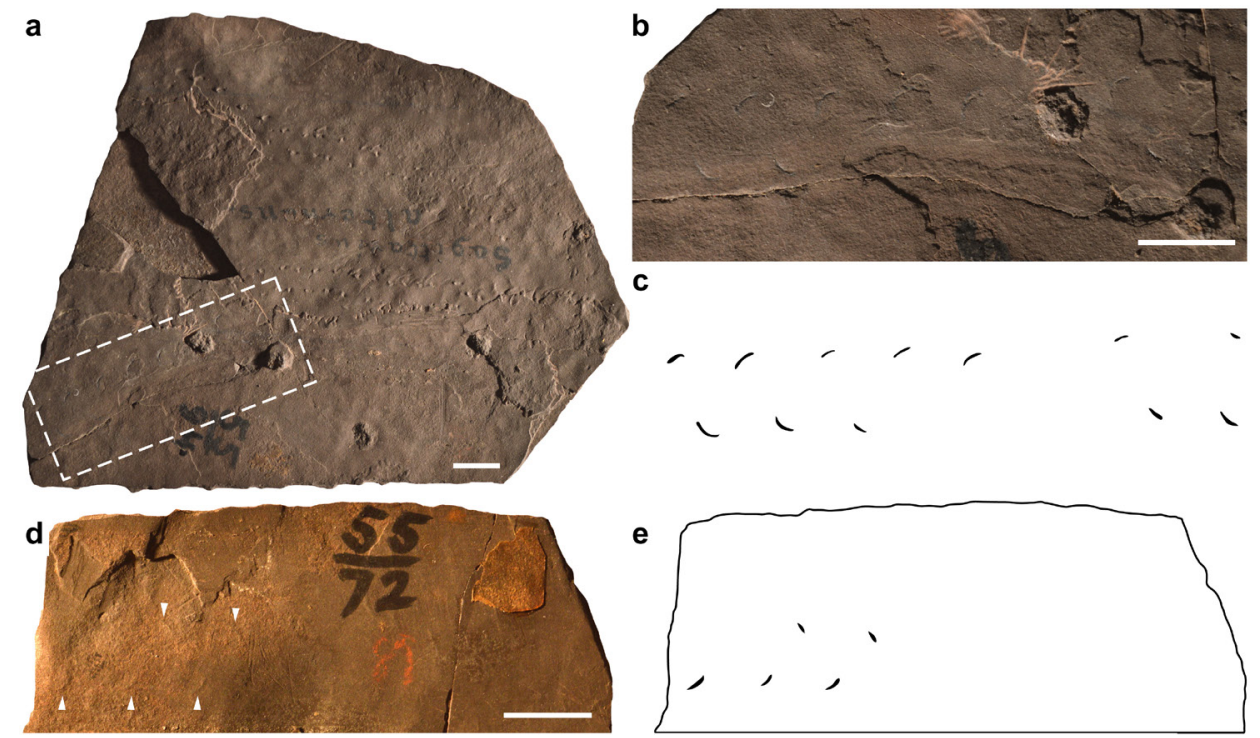

Figure 3 Hitchcock's Camurichnus alternans specimens. a) Photograph of ACM ICH 55/94, the slab on which the lectotype is preserved. b) Close-up photograph of the boxed region in a), showing a portion of the trackway. c) Line drawing of the portion of the trackway seen in b). d) Photograph of a portion of ACM ICH 55/94; the trackway is faint and individual tracks are indicated with arrowheads. e) Line drawing of the trackway in (d). Scale bars equal $10 \mathrm{~mm}$. 


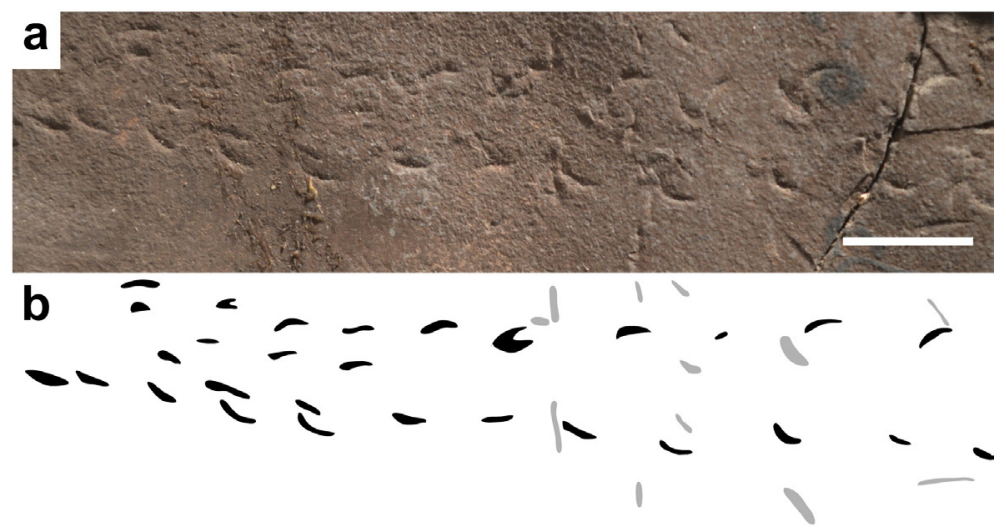

Figure 4 One of the Bifurculapes laqueatus trackways preserved on ACM ICH 36/33. a) Close-up photograph of the trackway. b) Interpretive line drawing. Tracks belonging to this trackway are shaded in black. Those belonging to other, overlapping trackways are shaded in gray for clarity. Scale bar equal $10 \mathrm{~mm}$.

Description. Trackways with external widths ranging from 0.4 to $0.9 \mathrm{~cm}$ and internal widths from 0.1 to $0.5 \mathrm{~cm}$. Tracks are arranged into staggered to alternating series of one to three, with two tracks per series being most common. Overlap between series is rare. The position of the third track is variable, even within a single trackway, where it might be positioned anterior or posterior to the other two tracks, or anywhere between; in a lateral direction, this track might occur close to the trackway midline or between the other two tracks. Individual tracks are straight or curved, and have outer track lengths ranging from 0.5 to $5.4 \mathrm{~mm}$ and inner track lengths ranging from 0.4 to $4.3 \mathrm{~mm}$. Outer tracks are typically oriented posterolaterally, with angles to midline ranging from $0^{\circ}$ to $57^{\circ}$, whereas inner tracks are oriented posterolaterally, posteromedially, or parallel to the trackway midline, with angles ranging from $-37^{\circ}$ to $32^{\circ}$. The repeat distance, or stride, ranges from 0.2 to $0.9 \mathrm{~cm}$. Medial drags are rare.

Remarks. Hitchcock (1865) described Camurichnus alternans (Figure 3) as a trackway having two rows (i.e., one track per series) of curved tracks that are concave inward and that occur in alternate symmetry. All of these characteristics, however, are visible in a portion of a Bifurculapes laqueatus trackway on ACM ICH 36/33 (Figure 4, right hand side). Upon examining other Bifurculapes trackways within the collections of the Beneski Museum of
Natural History, the Museum of Comparative Zoology, and the Peabody Museum of Natural History, at least eight additional trackways exhibit the characteristics of Camurichnus alternans along part of their course. Considering that the morphological characteristics that Hitchcock (1865) had used to distinguish Camurichnus alternans are present in Bifurculapes laqueatus, and that Bifurculapes laqueatus was erected earlier, the former is herein considered a junior subjective synonym of the latter.

The specimen on ACM ICH 55/94 has a longer stride than average for those Bifurculapes laqueatus with two to three tracks per series, which suggests that this variation in morphology might result from a gait change during locomotion, rather than result from undertracking.

Ichnogenus Hamipes Hitchcock, 1858

1858 Hamipes; Hitchcock, p. 150, plate 25 figure 8. 1889 Hamipes; Hitchcock, p. 119.

1915 Hamipes; Lull, p. 62.

1953 Hamipes; Lull, p. 47.

1975 Hamipes; Häntzschel, p. W67, figure 41.3. non 1997 Hamipes; Bolliger and Gubler, p. 619,

figures 4,5 .

non 2000 Hamipes; de Gibert et al., p. 93, figure

$3 \mathrm{~A}, \mathrm{~B}$. 
Type species. Hamipes didactylus Hitchcock, 1858, by monotypy.

Occurrence. Early Jurassic (Hettangian), Turners Falls Formation of the Deerfield Basin.

Emended Diagnosis. A trackway consisting of two rows of elongate, crescentic or j-shaped imprints arranged into series with staggered to alternating symmetry. Tracks approximately parallel to each other and to the trackway midline. The outer track is longer than the inner track. Inner and outer tracks are closely spaced and the negative space between the track rows accounts for $80-90 \%$ of the trackway width.

Remarks. As noted by Minter and Braddy (2009), Hamipes is similar to a number of other ichnotaxa that Hitchcock erected, including Acanthichnus, Bifurculapes, Camurichnus, Conopsoides, Copeza, Grammepus, Harpagopus, Harpepus, Lithographus, and Stratipes. Hamipes can be differentiated from these taxa, however, by a number of features. Among them is the number of tracks per series. Hamipes has only two tracks per series, whereas Bifurculapes, Copeza, Grammepus, and Lithographus have up to three tracks per series. Additionally, most Acanthichnus and Conopsoides have only one track per series. Hamipes can be differentiated from Harpagopus, Harpepus, and Stratipes, the latter two of which also have two tracks per series, by the orientation of the tracks. In Harpagopus, Harpepus, and Stratipes the tracks are oriented nearly perpendicular to the trackway midline, whereas in Hamipes they are oriented nearly parallel to the midline. Finally, Hamipes has much narrower track rows, relative to the size of the trackway, than similar taxa like Bifurculapes (Figure 5).

\section{Hamipes didactylus Hitchcock, 1858}

(Figure 6)

1858 Hamipes didactylus; Hitchcock, p. 150, plate

25 figure 8.

1889 Hamipes didactylus; Hitchcock, p. 119.

1915 Hamipes didactylus; Lull, p. 62.

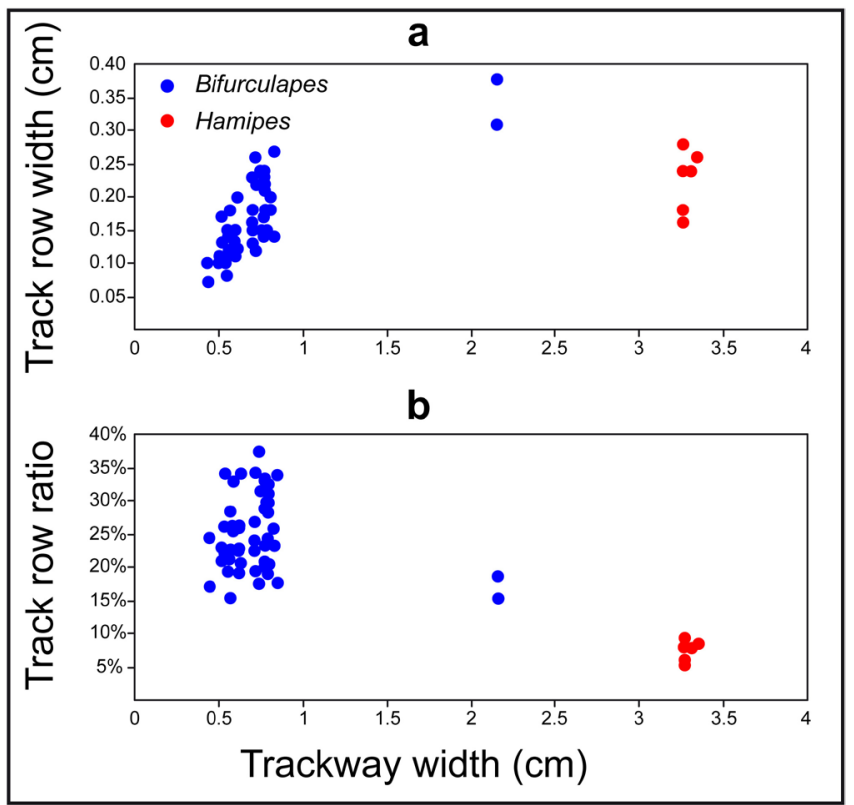

Figure 5 Comparison of trackway width and track row width in Bifurculapes and Hamipes. a) Plot showing track row width as measured. b) Plot showing track row width expressed as a percentage of overall trackway width. The large cluster of Bifurculapes points, on the left of the plots, is for B. laqueatus and its junior synonyms, whereas the two outliers, in the middle of the plot, are for B. scolopendroideus.

1953 Hamipes didactylus; Lull, p. 47.

1975 Hamipes didactylus; Häntzschel, p. W67, figure 41.3.

non 2000 Hamipes didactylus; de Gibert et al., p. 93, figure $3 \mathrm{~A}, \mathrm{~B}$.

Emended Diagnosis. As for the ichnogenus. Description. This species is known from a single trackway preserved in concave epirelief on a slab of gray shale. The trackway has an external width of $4.1 \mathrm{~cm}$ and an internal width of about 2.8 to 3.0 $\mathrm{cm}$. The tracks are thin $(c a .1 \mathrm{~mm})$ and crescent- or hook-shaped, and are arranged into staggered or alternating series of two. The hook-shaped tracks have an angle of $140^{\circ}$ to $146^{\circ}$ between the prongs. Within series, tracks are nearly parallel to slightly divergent. Lines drawn between the tips of curved tracks are parallel to the trackway axis, as are lines along the outer prong of $\mathrm{j}$-shaped tracks. The series are closely spaced but overlap (of up to 0.2 $\mathrm{cm})$ between them is rare. The repeat distance, or 

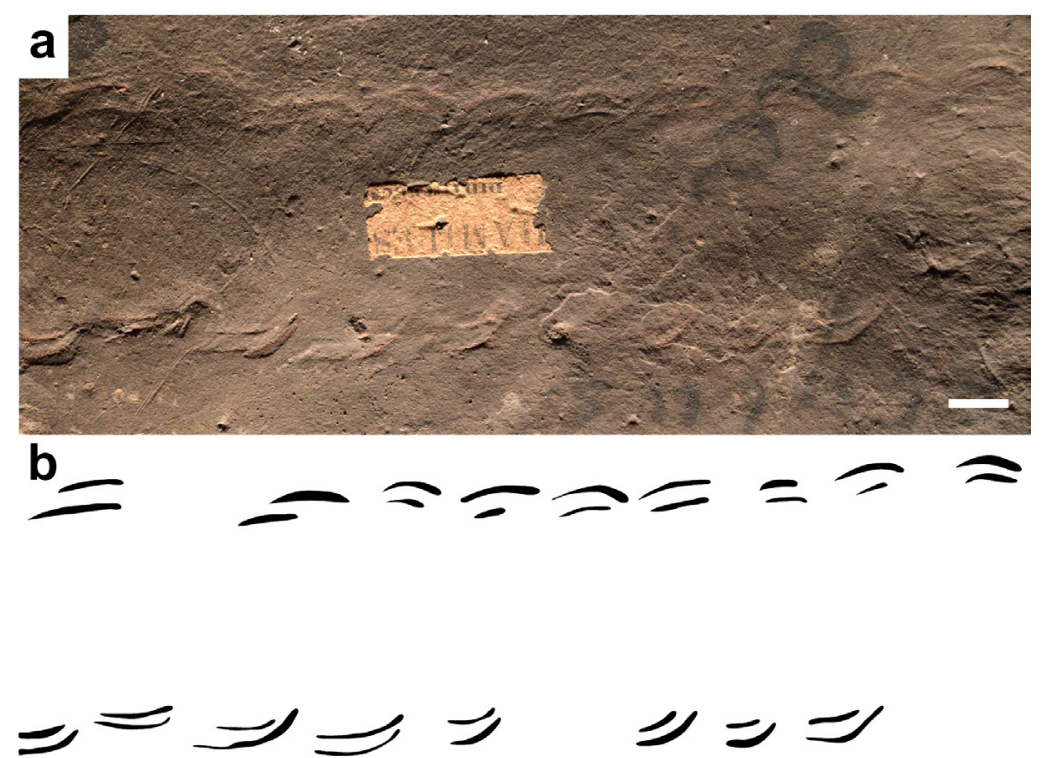

Figure 6 Hamipes didactylus lectotype. a) Photograph, and b) line drawing of a portion of the trackway, which is preserved on ACM ICH 36/16. Scale bar equals $10 \mathrm{~mm}$.

stride, is from 1.3 to $1.9 \mathrm{~cm}$. Outer track lengths range from 0.9 to $1.9 \mathrm{~cm}$, and their widths, across their curve, are from 0.1 to $0.4 \mathrm{~cm}$. Inner tracks are from 0.6 to $1.3 \mathrm{~cm}$ long and 0.1 to $0.2 \mathrm{~cm}$ wide across their curve.

Remarks. Hamipes has been reported twice outside the type locality. The first was by Bolliger and Gubler (1997), who attributed trackways from the Upper Freshwater Molasse of Switzerland to their new ichnospecies $H$. molassicus. The illustrated specimens of this ichnospecies, however, more closely resemble those of Hitchcock's (1858) ichnogenus Conopsoides, especially in terms of overall size, as well as shape and arrangement of the tracks. Most importantly, H. molassicus shares the upturned mounds of mud at the back of the tracks that Hitchcock considered diagnostic of Conopsoides. Consequently, H. molassicus is moved to Conopsoides, at least tentatively, pending a revision of that ichnogenus, which is underway and will be presented elsewhere.

De Gibert et al. (2000) provided the second report when they attributed trackways from the Cretaceous of Spain to Hamipes didactylus. These Cretaceous examples are, however, unlike the type specimen in that the tracks are straight and are often highly divergent from the midline of the trackway. Further, the track series have up to three tracks, and the negative space between the track rows is smaller. Rather, the Spanish specimens are much more similar to Bifurculapes and are herein reassigned to that ichnogenus. Thus, the Spanish fossils are the first occurrence of Bifurculapes in Europe and also the first unequivocal record of this ichnogenus from the Cretaceous Period.

\section{Discussion}

\subsection{GEOGRAPHIC AND STRATIGRAPHIC DISTRIBUTION}

Bifurculapes was first reported from the Deerfield Basin of Massachusetts (Hitchcock 1858, 1865), and Getty (2016) reported it from the adjoining Hartford Basin. C. H. Hitchcock (1889) reported Sagittarius, which is herein considered a junior subjective synonym of Bifurculapes, from Connecticut and New Jersey. Getty (2016) also reviewed the tentative occurrences of Bifurculapes from the Permian of France and Italy (Demathieu et al., 1992; Durand, 2001; Santi, 2006), the Triassic of 
Argentina (Melchor 2004), the Jurassic of Utah (Lucas et al., 2006; Milner et al., 2009), and the Cretaceous of Alaska (Fiorillo et al., 2009). He concluded that of these, the only specimen that should be included within Bifurculapes based on the information provided in the papers describing them was the one from Utah. Thus, the ichnogenus was restricted temporally to the Early Jurassic of North America.

Outside of its type locality, Hamipes has only been reported from Switzerland (Bolliger and Gubler, 1997) and Spain (de Gibert et al., 2000). With the removal of the Swiss and Spanish trackways from Hamipes, this ichnogenus is again known only from its type specimen, which was found in Early Jurassic rocks of the Deerfield Basin in Massachusetts.

\subsection{TRACKMAKERS}

When Hitchcock (1858) first described Bifurculapes and Hamipes, he proposed that the former was the work of insects or crustaceans and that the latter was made by a crustacean. He later (1865) was more specific about the maker of Bifurculapes, arguing that it was an insect. Most subsequent workers (e.g., Hitchcock, 1889; Lull, 1915, 1953; Mayoral, 2001) have also considered Bifurculapes to be an insect trackway. Getty (2016) suggested that the species B. laqueatus was likely the work of insects, and noted that the darkling beetle (Coleoptera: Tenebrionidae) trackways illustrated by Eiseman and Charney (2010) are similar to that ichnospecies. Demathieu et al. (1992), however, argued that possible specimens from France were most likely made by a triopsid crustacean, and de Gibert et al. (2000) proposed that their specimens were most likely made by astacid decapods. Getty (2016) suggested that Bifurculapes scolopendroideus, which is much larger than $B$. laqueatus, might have been produced by a crustacean based on its presence in lacustrine shale. Thus, it appears that different species of Bifurculapes might have had different makers. Lull (1915, 1953) considered Hamipes an arthropod trackway, but noted that it was unlikely to be an insect trace due to its size; he was otherwise non-committal in his placement of the ichnogenus, preferring to leave it in the incertae sedis. Hamipes is herein considered a crustacean trackway, however, and it should be noted that its presence in lacustrine shale, along with neoichnological experiments (Fairchild and Hasiotis, 2011) supports this inference.

\section{Conclusions}

The monospecific ichnogenera Camurichnus and Hamipes have been reevaluated and their geographic and stratigraphic ranges determined. Camurichnus, which was erected by Hitchcock (1865) as Sagittarius, is considered a junior subjective synonym of Bifurculapes because the characteristics used to distinguish it were discovered in a trackway of the latter ichnogenus. The species alternans is considered a junior subjective synonym of laqueatus. Hamipes is considered a distinct ichnogenus that can be differentiated from similar ichnotaxa by the number, shape, and arrangement of the tracks. Trackways that Bolliger and Gubler (1997) and de Gibert et al. (2000) attributed to Hamipes are more appropriately assigned to Conopsoides and Bifurculapes, respectively. This ichnogeneric reassignment restricts Hamipes to the Early Jurassic of Massachusetts in North America, but extends the geographic and stratigraphic range of Bifurculapes to the Cretaceous of Europe.

\section{Acknowledgements}

I thank Kate Wellspring and Hayley Singleton for allowing me access to specimens at the Beneski Museum of Natural History. I also thank Jessica Cundiff, of the Museum of Comparative Zoology, and Susan Butts, of the Yale Peabody Museum, for granting me permission to examine the Bifurculapes specimens in their care. I appreciate the hospitality of Gary and Laurie Gaulin, who have allowed me to conduct field work on their property. I am also indebted to Sebastian Dalman for making the Gaulin site known to me, and to Robert Sproule for 
discovering the Bifurculapes specimen that piqued my interest in Hitchcock's arthropod trackways. Sam Loeb drafted the bedrock geology map illustrated in Figure 1c. Finally, I thank Giuseppe Santi and Francisco Vega for providing useful scientific reviews, and Juan Pablo Carrillo for his thorough technical review.

\section{References}

Bertling, M., Braddy, S.J., Bromley, R.G., Demathieu, G.R., Genise, J., Mikuláš, R., Nielsen, J.K., Nielsen, K.S.S., Rindsberg, A.K., Schlirf, M., Uchman, A., 2006, Names for trace fossils: a uniform approach: Lethaia, 39(3), 265-286.

Bolliger, T., Gubler, T., 1997, Arthropodenlaufspuren von Hochdorf (LU) und weitere Arthropodennachweise aus der Oberen Süsswassermolasse der Schweiz: Eclogae Geologicae Helvetiae, 90, 617-627.

Demathieu, G., Demathieu, P., 2003, Concerning the Erection of Ichnogenera and Ichnospecies in Vertebrate Ichnotaxonomy: Ichnos, 9, 117-121.

Demathieu, G., Gand, G., Toutin-Morin, N., 1992, La palichnofaune des bassins permiens provençaux: Geobios, 25(1), 19-54.

Durand, M., 2001, The continental PermianTriassic series of Provence (southeast France), in International Field Conference on the Stratigraphic and Structural Evolution of the Late Carboniferous to Triassic Continental and Marine Successions in Tuscany (Italy), Field trip guidebook: Siena, Italy, Regional Reports and General Correlations, 29 p.

Eiseman, C., Charney, N., 2010, Tracks \& Sign of Insects and Other Invertebrates: A Guide to North American Species: Mechanicsburg, U.S.A., Stackpole Books, 582 p.
Fairchild, J.M., Hasiotis, S.T., 2011, Terrestrial and aquatic neoichnological laboratory experiments with the freshwater crayfish Orconectes: trackways on media of varying grain size, moisture, and inclination: Palaios, 26(12), 790-804.

Fiorillo, A.R., Hasiotis, S.T., Kobayashi, Y., Tomsich, G.S., 2009, A pterosaur manus track from the Denali National Park, Alaska Range, Alaska, United States: Palaios, 24(7), 466-472.

Getty, P.R., 2016, Bifurculapes Hitchcock 1858: a revision of the ichnogenus: Atlantic Geology, $52,247-255$.

de Gibert,J.M., Fregenal-Martínez, M.A., Buatois, L.A., Mángano, M.G., 2000, Trace fossils and their palaeoecological significance in Lower Cretaceous lacustrine conservation deposits, El Montsec, Spain: Palaeogeography, Palaeoclimatology, Palaeoecology, 156, 89-101.

Goldstein, D.H., Getty, P.R., Bush, A.M., 2017, Hitchcock's treptichnid trace fossils (Jurassic, Massachusetts, USA): conflicting interpretations in the "Age of Fucoids": Bollettino della Società Paleontologica Italiana, 56(2), 109-116.

Häntzschel, W., 1975, Trace fossils and problematica, in Teichert, C. (ed.), Treatise on Invertebrate Paleontology, Part W, Miscellanea, supplement 1: Boulder, Colorado and Lawerence, Kansas, The Geological Society of America and The University of Kansas, W2-W269.

Hermann, J., 1783, Tabula affinitatum animalium olim academico specimine edita, nunc uberiore commentario illustrata cum annotationibus ad historiam naturalem animalium augendam facientibus: Strasbourg, France, Georgh Treuttel, 371 p.

Hitchcock, G.H., 1889, Recent progress in ichnology: Proceedings of the Boston Society of Natural History, 24, 117-127. 
Hitchcock, E., 1858, Ichnology of New England. A report on the sandstone of the Connecticut Valley, especially its fossil footmarks, Made to the Government of the Commonwealth of Massachusetts: Boston, U.S.A., William White, 220 p.

Hitchcock, E., 1865, Supplement to the ichnology of New England. A report to the Government of Massachusetts, in 1863: Boston, U.S.A., Wright and Potter State Printers, 96 p.

Hubert, J.F., 1978, Paleosol caliche in the New Haven Arkose, Newark Group, Connecticut: Palaeogeography, Palaeoclimatology, Palaeoecology, 24(2), 151-168.

Hubert J.F., Dutcher J.A., 2005, Synsedimentary sand pillows of a lacustrine delta slope (Turners Falls Formation) and sheetflood deposition of alluvial-fan gravels (Mount Toby Formation), Early Jurassic Deerfield Basin, Massachusetts: Northeastern Geology \& Environmental Sciences, 27, 18-36.

Keighley, D.G., Pickerill, R.K., 1998, Systematic ichnology of the Mabou and Cumberland groups (Carboniferous) of western Cape Breton Island, eastern Canada, 2: surface markings: Atlantic Geology, 34, 83-112.

Lucas, S.G. Lerner, A.J., Milner, A.R.G., Lockley, M.G., 2006, Lower Jurassic invertebrate ichnofossils from a clastic lake margin, Johnson Farm, southwestern Utah, in Harris, J.D., Lucas, S.G., Spielmann, J.A., Lockley, M.G., Milner, A.R.C., Kirkland, J.I. (eds.), The Triassic-Jurassic terrestrial transition: Albuquerque, U.S.A., New Mexico Museum of Natural History \& Science Bulletin, 37, 128-136.

Lull, R.S., 1915, Triassic life of the Connecticut Valley: Hartford, U.S.A., State Geological and Natural History Survey Bulletin, 24, 1-285.

Lull, R.S., 1953, Triassic life of the Connecticut Valley, revised: Hartford, U.S.A., State Geological and Natural History Survey Bulletin, 81, 1-336.
Mayoral, E., 2001, Pistas fósiles de artrópodos: Boletín de la Sociedad Entomológica Aragonesa, 28, 15-33.

Melchor, R.N., 2004, Trace fossil distribution in lacustrine deltas: examples from the Triassic rift lakes of the IschigualastoVilla Unión basin, Argentina, in McIlroy, D. (ed.), The application of ichnology to palaeoenvironmental and stratigraphic analysis: London, England, Geological Society Special Publication, 228, 335-354.

Milner, A.R.G., Harris, J.D., Lockley, M.G., Kirkland, J.I., Matthews, N.A., 2009. Birdlike anatomy, posture, and behavior revealed by an Early Jurassic theropod dinosaur resting trace: PLoS ONE, 4(3), e4591.

Minter, N.J., Braddy, S.J., 2009, Ichnology of an Early Permian intertidal flat: the Robledo Mountains Formation of southern New Mexico, USA: Special Papers in Palaeontology, 82, 1-107.

Minter, N.J., Braddy, S.J., Davis, R.B., 2007, Between a rock and a hard place: arthropod trackways and ichnotaxonomy: Lethaia, 40(4), 365-375.

Olsen, P.E., 1978, On the use of the term Newark for Triassic and Early Jurassic rocks of eastern North America: Newsletters on Stratigraphy, 7(2), 90-95.

Olsen, P.E., 1986, A 40-million-year lake record of early Mesozoic orbital climatic forcing: Science, 234(4778), 842-848.

Olsen, P.E., McDonald, N.G., Huber, P, Cornet, B., 1992, Stratigraphy and paleoecology of the Deerfield Rift Basin (Triassic-Jurassic, Newark Supergroup), Massachusetts, in Robinson, P., Brady, J.B. (eds.), Guidebook for field trips in the Connecticut Valley region of Massachusetts and adjacent states, 84th Annual Meeting New England Intercollegiate Geological Conference: Amherst, U.S.A., Amherst College, Smith College, Mount Holyoke College, Hampshire College, University of Massachusetts, 2, 488-535. 
Olsen, P.E., Schlische, R.W., Fedosh, M.S., 1996, 580 Ky Duration of the Early Jurassic Flood Basalt Event in Eastern North America Estimated Using Milankovitch Cyclostratigraphy, in Morales, M. (ed.), The Continental Jurassic: Museum of Northern Arizona Bulletin, 60, 11-22.

Parrish, J.T., 1993, Climate of the Supercontinent Pangea: The Journal of Geology, 101(2), 215-233.

Rainforth, E.C., 2005, Ichnotaxonomy of the fossil footprints of the Connecticut Valley (Early Jurassic, Newark Supergroup, Connecticut and Massachusetts): New York, U.S.A., Columbia University, Ph.D. dissertation, $1264 \mathrm{p}$.

Rasband, W.S., 1997-2015, ImageJ: Bethesda, U.S.A., U.S. National Institutes of Health, available in <http://imagej.nih.gov/ij/>, access March 2015.
Santi, G., 2006, Lower Permian invertebrate ichnocoenosis from the Orobic Basin, northern Italy: Bollettino della Società Paleontologica Italiana, 45, 201-212.

Schlische, R.W., Olsen, P.E., 1990, Quantitative Filling Model for Continental Extensional Basins with Applications to Early Mesozoic Rifts of Eastern North America: The Journal of Geology, 98(2), 135-155.

Vosmaer, A., 1769, Description d'un Oiseau de Proie, Nommé le Sagittaire, tout-à-fait inconnu jusqu'ici; apporté du Cap de Bonne Espérance: Amsterdam, The Netherlands, Pierre Meijer, 9 p.

Zen, E-An, Goldsmith, R., Ratcliffe, N.M., Robinson, P., Stanley, R.S., Hatch, N.L., Shride, A.F., Weed, E.G.A., Wones, D.R., 1983,Bedrock geologic map of Massachusetts, scale 1:250,000: Massachusetts, U.S.A., The Commonwealth of Massachusetts, Department of Public Works, United States Geological Survey, 1 map. 